\title{
POSSIBILITY OF USING RIBS TO PROTECT PIPELINES FROM THE LONG CRACK PROPAGATION
}

\author{
Baraa M.H. Albaghdadi, ${ }^{1,2}$, baraa.albaghdadi@gmail.com, \\ A.O. Cherniavsky ${ }^{1}$, a.o.cher@mail.ru \\ ${ }^{1}$ South Ural State University, Chelyabinsk, Russian Federation \\ ${ }^{2}$ University of Technology, Baghdad, Iraq
}

\begin{abstract}
This research aims to build a finite element model of oil or gas steel pipelines transmission. The model has been developed in that crack propagation in pipes can be reduced as possible to avoid the failure. The suggestion that is taken into consideration for this purposeis to stopping crack propagation as possibly, is by using ribs as arresters. Different thicknesses have been tested for the ribs used in this study. The first one was of $0.02 \mathrm{~m}$, while as the second thickness was of $0.05 \mathrm{~m}$. The dimensions of pipe are of $0.01 \mathrm{~m}$ thickness, and diameter of $0.5 \mathrm{~m}$. The model of pipe consists of three parts. The first part has two different lengths $2 \mathrm{~m}$ and $3 \mathrm{~m}$. The second, which is the rib, is of length of $0.15 \mathrm{~m}$. The third part of pipe has the length of $1 \mathrm{~m}$. So all the three parts are made up the case study that was studied in this work. The value of stress intensity factor $K 1$ for different lengths of cracks has been calculated by the finite element model developed by using ANSYS package. These calculations were applied with and without ribs. The results showed that when using the ribs, the stress intensity factor would be reduced significantly. This leads to reduce the possibility of failure.
\end{abstract}

Keywords: pipe (pipeline), crack, crack arrest, crack propagation, long crack, stress intensity factor, FEM.

\section{Introduction}

Natural gas and petroleum transmission pipeline system is one of the most important infrastructures and is considered as economic and safe way, that is used worldwide efficiently of transporting a large volume of natural gas or crude oil over a long distance [1-3]. One of the challenges facing the oil and gas industry is the assurance of more reliable and fail-safe operations of the infrastructure for production and transportation [4]. Modern gas steel pipelinesare built with large-diameter, thin-wall pipes in highstrength, high-toughness steels, and is designed to be worked under high internal pressure with high performance. As well as to reduce the cost of construction and operation for a pipeline system $[1,3,5]$. In order to maintain structural integrity of components such as large-diameter pipelines and to prevent fracture by unstable longitudinal dynamic propagation of cracks, a minimum toughness level is required for pipeline steels [6].

A lot of studies have been published in this field. An experimental-numerical method has been proposed by [7] for estimation of the conditions of fracture of gas pipelines. In this study the efficiency of the numerical-analytic approach to the evaluation of the kinetics and changes in the shapes of corrosion fatigue defects in the course of their propagation in the wall of the pipeline was experimentally demonstrated. They determined the conditions under which the catastrophic failures of pipes become possible after long-operation.

Dynamic analysis relating to rapid crack propagation (RCP) and arrest in gas pipelines were considered by [8], based on a fluid/structure/fracture interaction package, PFRAC to simulate the behavior of the fractured pipes. Growing cracks dynamically also have been studied by [9], depending on developing a three-dimensional finite-deformation cohesive element and a class of irreversible cohesive laws which enable the accurate and efficient tracking of growing cracks.

The use of steel rings as crack arrestor devices in steel gas transmission pipelines is to prevent the possibility of long running axial cracks wasdone by [10]. These arrestors have used to reduce the danger of the pipe opening as the crack is propagating. This leads to decrease the available crack driving force and, as a result, crack arrest can be done. In the work of [11] the mechanical properties (strength, plasticity, strain aging sensitivity, impact toughness, resistance to crack nucleation and propagation) of a steel are investigated for different sections of pipe forming [12]. Showed that prevention of shear fracture in 


\section{Расчет и конструирование}

the natural gas pipelines is one of the most important problems for the safety of the natural gas transportation. In their work, was developed a prediction method for the crack propagation and arrest in the ultrahigh pressure pipelines.

The value of the stress intensity factor $K 1$, which depends on the loading mode, is evaluated by different methods developed by many researchers [13]. A dynamic finite element analysis method was proposed by [14] for calculating the dynamic stress intensity factors for pipes during crack propagation. Their method can directly calculate the stress intensity factors without the simplification used in theoretical analyses, and it can consider the effects of the crack velocity and gas decompression. In the work of [15] a new governing equation for the dynamic crack propagation based on the momentum balance principle was presented. The prediction of the dynamic crack as a function of the time, the material dynamic fracture properties, including pipeline limiting crack speed, and the conditions to obtain leak before break were obtained in their study.

The fracture mechanics analysis in ANSYS for cylindrical panels with surface cracks were considered by [16]. They proposed a universal formula for determining the stress intensity factor value. In the present study, which depends on for modelling using the finite element method, the value of the stress intensity factor $(K 1)$ has been computation for models with and without ribs.

\section{Long cracks on pipelines}

Generally, the long crack growth and fracture only amount to a small part of the total life of the pipeline, whereas, a significant part of the total life is consumed at stages before the long crack growth threshold is exceeded [17]. The gas pipelines consist of thousands of pipes. In the course of their long life of more than 35 years different crack_like defects accumulate which can lead to the destruction of pipes with oil and gas leakage [18]. The risk of fracture increases at low climatic temperatures, degradation and strain aging of steel which causes in plasticity drop [19].

According to the statistics of American National Standards Institute, the economic loss of one hundred billion US dollars, about $4.2 \%$ of gross national product, in the USA is caused by material fracture; one-third of the loss could be protected and avoided by known technologies, and one-fourth of it could be reduced by research and development [20].

If the fracture occurs in a natural gas pipeline, the consequence can be severed to its safe operation and to the people, property and environment local to the pipeline, and may result in large economic losses [1]. There have been a number of catastrophic instances where cracks have propagated in a rapid manner for a few kilometers in steel gas transmission pipelines [8]. Crack arrest in steel line pipe depends on the fracture and flow properties of the steel [21]. Fatigue failures can occur through a threestage process: crack initiation (Stage I), propagation (Stage II) and final rupture (Stage III) [22]. Fig.1 shows long crackon pipeline.

\section{Opportunity to use ribs for crack arrest}

The rib method has suggested to use for stopping or reducing possibility of the failure of long crack propagation in oil or gas pipelines. For this purpose FEM (Finite element method) is used. ANSYS package has been adopted to achieve pipe model and verification of the results. The case study model used for this work is part of steel pipeline with the following dimensions: pipe thickness of $0.01 \mathrm{~m}$, and diameter of pipe of $0.5 \mathrm{~m}$. The pipe consists of three parts. The first part is of length $(l) 2 \mathrm{~m}$ and the second is the rib with length $\left(l_{1}\right) 0.15 \mathrm{~m}$. The third part of pipeline has the length of $1 \mathrm{~m}$. The all of the three parts are made up the case study that is studied in this work as shown in Fig. 2. For reducing time calculations, the half pipe with symmetry boundary conditions has been used. In the models of the pipelines, different lengths for cracks $(x)$ have used in the first part in such that ordering started from the first point in the direction of rib to the tip point of crack. This case study was repeated again, but with different dimension of the first part of pipeline $(l)$. This dimension is $3 \mathrm{~m}$ instead of $2 \mathrm{~m}$. This is to check if there is need more ribs or not.

The pressure used during the building of model by ANSYS is $5 \mathrm{Mpa}$ and the other conditions are fixed excepting the length of the crack that waschanged from short crack $0.25 \mathrm{~m}$ and increased towards the rib's part. In addition to that, different thicknesses of ribs have been used. The first of them is $0.02 \mathrm{~m}$ the second one is $0.05 \mathrm{~m}$. For comparison, the same models have been applied but without rib, that represents the default thickness $(0.01 \mathrm{~m})$. In all models, $K 1$ (stress intensity factor) has been calculated. 


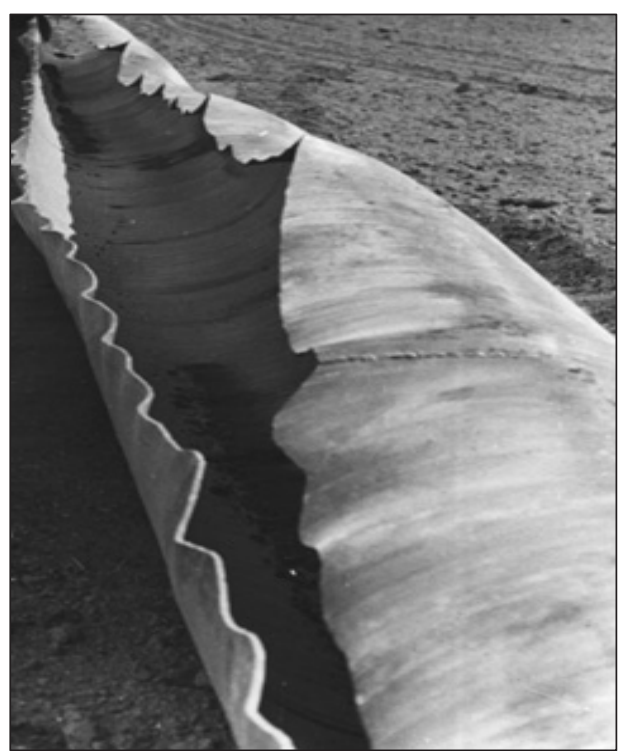

Fig. 1. Long crack on pipeline

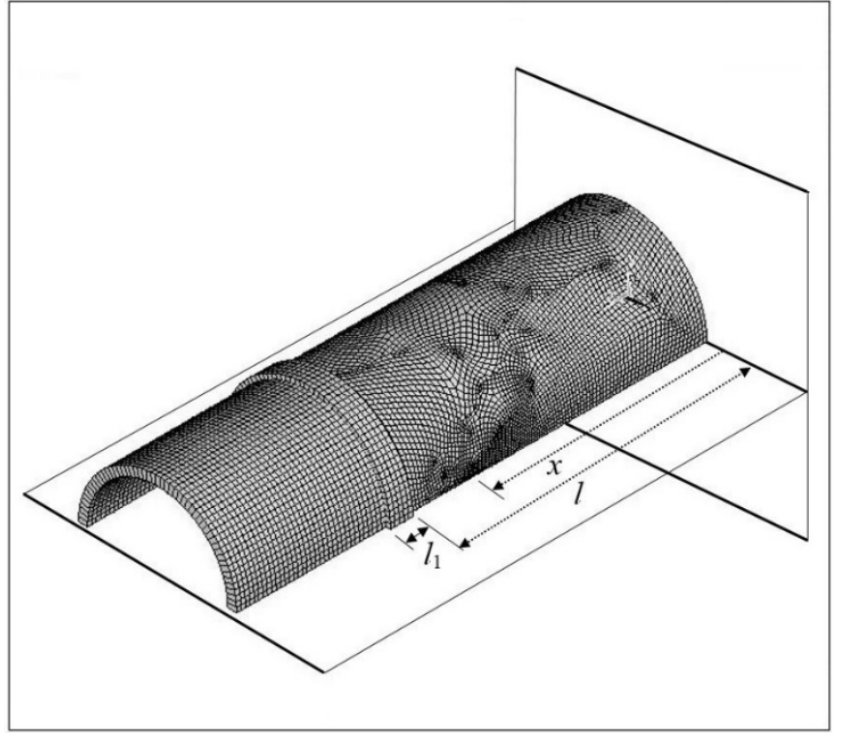

Fig. 2. The case study model with rib clarifies symmetry boundary

The relationship between crack's length and $K 1$ for all cases (with ribs in different thicknesses and without rib) is shown as in fig. 3, while the fig. 4 shows the same relationship with dimension $3 \mathrm{~m}$ for the first part of pipe. In this figures it could be noticed that the stress intensity factor decreaseswith ribs significantly if it is compared with the stress intensity factor without rib. Fig. 5 shows the relationship between of first part length of the pipe models and $k$ ratio that represents the rate of $K 1$ (minimum with rib) $/ K 1$ (without rib). From the figure, it can be noticed that the length of the first part of pipeline doesn't have much effect on using more numbers of ribs. In other words it can be used ribs with long distances of each other.

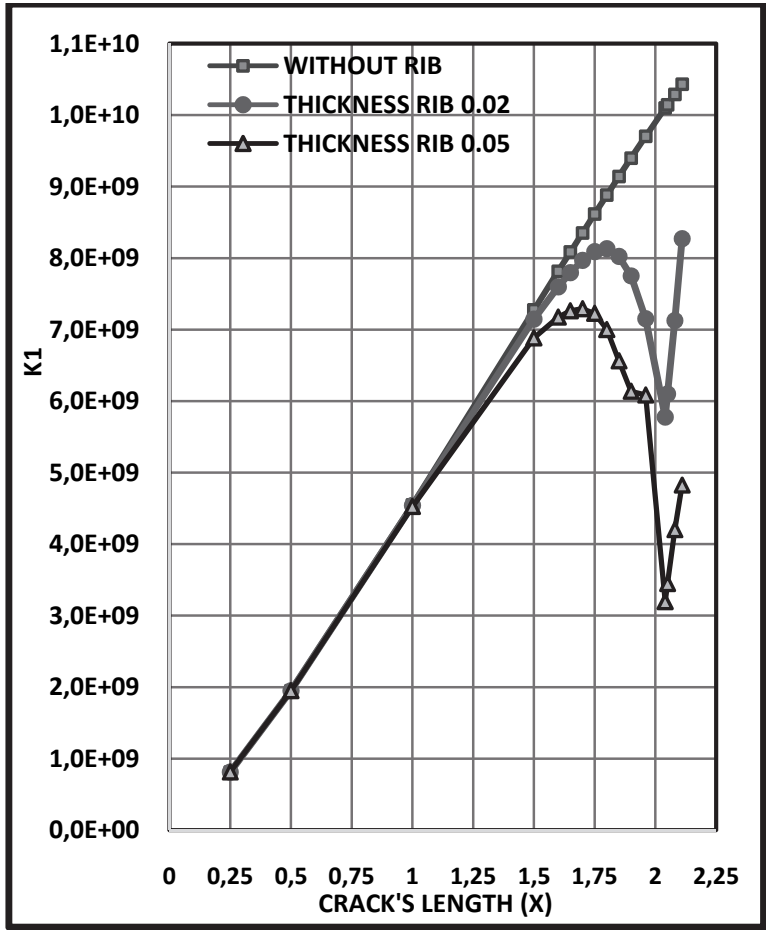

Fig. 3. Relationship between crack's length and $K 1$ with and without ribs for the pipe which its first part longs $\mathbf{2} \mathrm{m}$

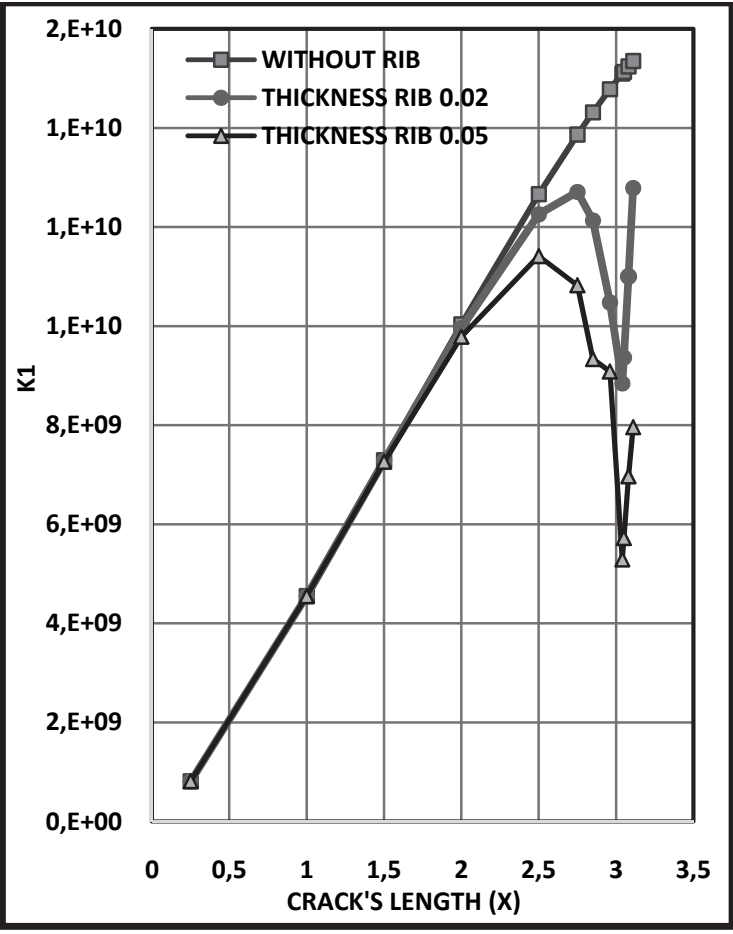

Fig. 4. Relationship between crack's length and $K 1$ with and without ribs for the pipe which its first part longs $3 \mathrm{~m}$ 


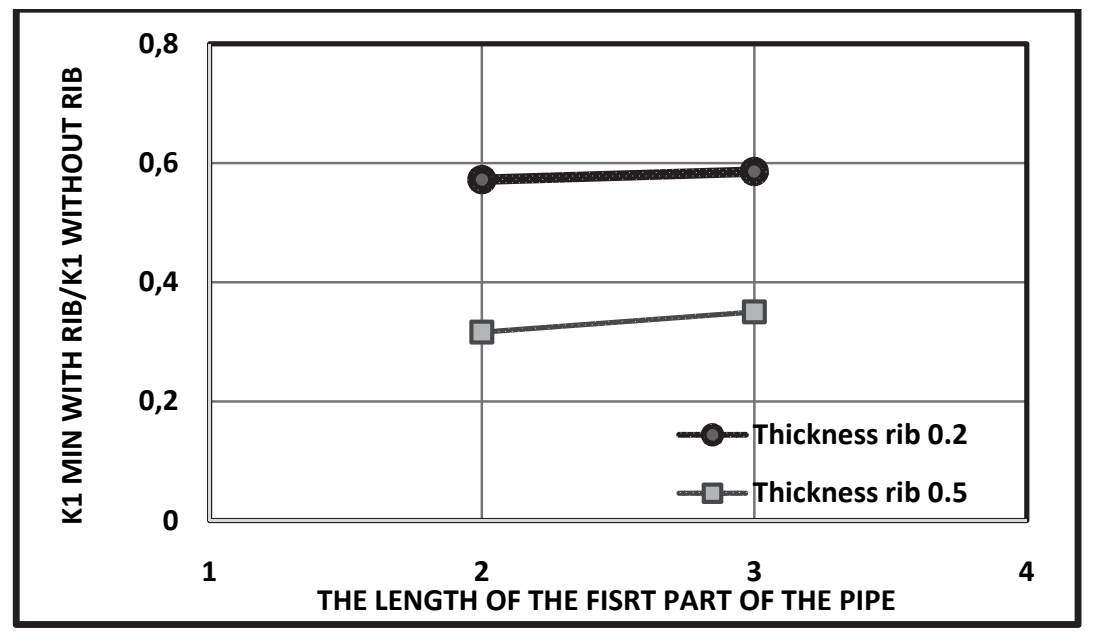

Fig. 5. Relationship between of first part length of the pipe and $\mathrm{k}$ ratio

\section{Conclusion}

In this study, a finite element model (FEM) has been developed for steel pipelines used in transporting oil or gas by using the ribs as arresters of crack propagation. The results showed that the use of ribs plays an important role in reducing the stress intensity factor, $K 1$, which in turn, considers measurable value to reduce the crack propagation. As a result for that, the possibility of reducing the ricks of pipelines failure will be reduced. The results also showed that the rib used of thickness of $0.05 \mathrm{~m}$ is better than the rib with $0.02 \mathrm{~m}$ thickness. More thing is in the case of using pipe with first part $2 \mathrm{~m}$ or $3 \mathrm{~m}$, there is no very important difference in decreasing $k$ ratio. That leads to use less numbers of ribs. Therefore, the ribs can be used to protect the gas and oil pipelines of growth cracks and failure.

\section{References}

1. Zhu X.-K. State-of-the-art review of fracture control technology for modern and vintage gas transmission pipelines. Engineering Fracture Mechanics, 2015, vol. 148, pp. 260-280. DOI: 10.1016/j.engfracmech.2015.05.055

2. Yang Y., Shi L., Xu Z., Lu H., Chen X., Wang X. Fracture toughness of the materials in welded joint of X80 pipeline steel. Engineering Fracture Mechanics, 2015, vol. 148, pp. 337-349. DOI: 10.1016/j.engfracmech.2015.07.061

3. Shin S.Y., Hwang B., Lee S., Kima N.J., Ahnc S.S. Correlation of microstructure and charpy impact properties in API X70 and X80 line-pipe steels. Materials Science and Engineering: A, 2007, vol. 458, iss. 1-2, pp. 281-289. DOI: 10.1016/j.msea.2006.12.097

4. Souza R.F., Ruggieri C. Fracture assessments of clad pipe girth welds incorporating improved crack driving force solutions. Engineering Fracture Mechanics, 2015, vol. 148, pp. 383-405. DOI: 10.1016/j.engfracmech.2015.04.029

5. Beden S.M. Environment Effects on Fatigue Crack Growth Rate in API 5L X70 and X80 Steel Pipelines. International Journal of Engineering research and science technology, 2014, vol. 3, no. 2, pp. 333-343.

6. Rivalin F., Besson J., Pineau A., Fant M.D. Ductile tearing of pipeline-steel wide plates II. Modeling of in-plane crack propagation. Engineering Fracture Mechanics, 2001, vol. 68, pp. 347-364. DOI: $10.1016 / \mathrm{S} 0013-7944(00) 00108-9$

7. Kryzhanivs'kyi E.I., Hrabovs'kyi R.S., Fedorovych I.Ya., Barna R.A. Evaluation of the Kinetics of Fracture of Elements of a Gas Pipeline after Operation. Materials Science, 2015, vol. 51, iss. 1, pp. 7-14. DOI: 10.1007/s11003-015-9804-1

8. Zhuang Z., O'donoghue P.E., The recent development of analysis methodology for rapid crack propagation and arrest in gas pipelines. International Journal of Fracture, 2000, vol. 101, iss. 3, pp. 269-290. DOI: 10.1023/A:1007614308834 
9. Ortiz M., Pandolfi A. Finite-Deformation Irreversible Cohesive Elements for Three-Dimensional Crack-Propagation Analysis. International Journal for Numerical Methods in Engineering, 1999, vol. 44, is. 9, pp. 1267-1282. DOI: 10.1002/(SICI)1097-0207(19990330)44:9<1267::AID-NME486>3.0.CO;2-7

10. O'donoghueand P.E., Zhuang Z. A finite element model for crack arrestor design in gas pipelines. Fatigue \& Fracture of Engineering Materials \& Structures, 1999, vol. 22, iss. 1, pp. 59-66. DOI: 10.1046/j.1460-2695.1999.00139.x

11. Shabalov I.P., Solov'ev D.M., Filippov G.A., Livanova O.V. Mechanical Properties of a Pipe Workpiece at the Stages of JCOE Pipe Forming. Russian Metallurgy (Metally), 2015, vol. 2015, iss. 4, pp. 309-316. DOI: 10.1134/S003602951504014X

12. Makino H., Kubo T., Shiwaku T., Endo S., Inoue T., Kawaguchi Y., Matsumoto Y., Machida S. Prediction for Crack Propagation and Arrest of Shear Fracture in Ultra-high Pressure Natural Gas Pipelines. ISIJ International, 2001, vol. 41, no. 4, pp. 381-388. DOI: 10.2355/isijinternational.41.381

13. Ibrahim R.A. Overview of Structural Life Assessment and Reliability, Part V: Joints and Weldments. Journal of Ship Production and Design, 2016, vol. 32, no. 1, pp. 1-20. DOI: 10.5957/JSPD.32.1.130025-5

14. Mitsuya M., Motohashi H., Oguchi N., Aihara S. Calculation of Dynamic Stress Intensity Factors for Pipes During Crack Propagation by Dynamic Finite Element Analysis. J. Pressure Vessel Technol., 2013, vol. 136, iss. 1. DOI: 10.1115/1.4025617

15. Murtagian G.R., Ernst H.A. Dynamic axial crack propagation in steel line pipes. Part II: Theoretical developments. Engineering Fracture Mechanics, 2005, vol. 72, iss. 16, pp. 2535-2548. DOI: 10.1016/j.engfracmech.2005.03.004

16. Glushkov S.V., Skvortsov Yu.V. Fracture Mechanics Analysis of Cylindrical Panels with NonThrough Cracks. Russian Aeronautics, 2014, vol. 57, iss. 3, pp. 240-244. DOI: 10.3103/S1068799814030040

17. Elboujdaini M., Fang B., Eadie R. Canadian Experience in SCC of Pipelines and Its Remedies. Recent Progress in SCC of Pipelines in Near-Neutral pH Environment. Integrity of Pipelines Transporting Hydrocarbons. Springer Netherlands, 2011, vol. 1, ch. 8, pp. 99-114. DOI: 10.1007/978-94-007-0588-3_8

18. Kucheryavyi V.I., Mil'kov S.N. Statistical Modeling of the Residual Life of an Oil and Gas Pipeline with Axial Crack-Like Defects. Journal of Machinery Manufacture and Reliability, 2014, vol. 43, iss. 1, pp. 82-87. DOI: 10.3103/S1052618814010117

19. Matvienko Yu.G. A Damage Evolution Approach in Fracture Mechanics of Pipelines. Integrity of Pipelines Transporting Hydrocarbons of the NATO Science for Peace and Security Ser. C: Environmental Security, 2011, vol. 1, pp. 227-244. DOI: 10.1007/978-94-007-0588-3_15

20. Huang H.-S. Fracture Characteristics Analysis of Pressured Pipeline with Crack Using Boundary Element Method. Advances in Materials Science and Engineering, 2015, vol. 2015, 13 p. DOI: $10.1155 / 2015 / 508630$

21. Hari Manoj Simha C. A model for arrest of rapid cracks in gas-pressurized ductile steel line pipe. Engineering Fracture Mechanics, 2016, vol. 154, pp. 245-261. DOI: 10.1016/j.engfracmech.2015.12.009

22. Yu M., Chen W., Kania R., Boven G.V., Been J. Crack propagation of pipeline steel exposed to a near-neutral $\mathrm{pH}$ environment under variable pressure fluctuations. International Journal of Fatigue, 2016, vol. 82, pp. 658-666. DOI: 10.1016/j.jifatigue.2015.09.024

Received 22 July 2016 


\title{
ВОЗМОЖНОСТЬИСПОЛЬЗОВАНИЯ РЕБЕР ДЛЯ ЗАЩИТЫТРУБОПРОВОДОВ ОТ РАСПРОСТРАНЕНИЯ ПРОДОЛЬНЫХ ТРЕЩИН
}

\author{
Бара М.Х. Албагдади ${ }^{1,2}$, А.О. Чернявский ${ }^{1}$ \\ ${ }^{1}$ Южно-Уральский государственный университет, г. Челябинск, \\ ${ }^{2}$ Технологический университет, Багдад, Ирак
}

\begin{abstract}
Наибольшие разовые экономические и экологические потери при авариях на магистральных трубопроводах связаны с появлением длинных продольных трещин, сопровождающимся разливами значительных количеств нефти, взрывами и пожарами. Современным путем для предотвращения таких трещин является использование вязких сталей, однако повышение вязкости разрушения, достигаемое за счет легирования и термообработки, ведет к существенному удорожанию труб. В качестве более дешевой альтернативы может быть рассмотрено конструктивное торможение трещин - например, с помощью локальных утолщений (ребер), расстояние между которыми лимитирует длину продольной трещины (в ряде случаев трещина длиной до 10 м является допустимой). При наличии дешевой технологии создания таких ребер ключевым вопросом является их эффективность.

Целью работы являлось построение конечно-элементной модели трубы магистрального трубопровода с трещиной для оценки возможности предотвращения развития длинных продольных трещин с помощью окружных ребер. Ребра представляют собой утолщения плавной формы. Была протестирована эффективность ребер различной толщины - в 2 и в 5 раз превышающей толщину стенки трубы. Модель включала участок трубы с трещиной, ограниченный с двух сторон ребрами, и необходимую часть трубы снаружи ребер. В качестве параметра, характеризующего распространение трещины, в первом приближении использовался коэффициент интенсивности напряжений $K 1$, значения которого определялись численно с использованием пакета ANSYS. Расчеты показали, что при использовании ребер коэффициент интенсивности напряжений может быть значительно уменьшен, и ребра могут быть использованы для торможения (остановки) трещины.

Ключевые слова: труба (трубопровод), трещина, задержка трещчины, распространение трещины, длинные трещины, коэффицичент интенсивности напряжений, FЕМ.
\end{abstract}

Бара Мохсен Хоссеин Албагдади, аспирант кафедры прикладной механики, динамики и прочности машин, Южно-Уральский государственный университет, г. Челябинск; преподаватель, Технологический университет, г. Багдад, Ирак, baraa.albaghdadi@gmail.com.

Чернявский Александр Олегович, доктор технических наук, кафедры прикладной механики, динамики и прочности машин, Южно-Уральский государственный университет, г. Челябинск, a.o.cher@mail.ru.

Поступила в редакцию 22 июля 2016 г.

\section{ОБРАЗЕЦ ЦИТИРОВАНИЯ}

Baraa M.H. Albaghdadi. Possibility of using ribs to protect pipelines from the long crack propagation / Baraa M.H. Albaghdadi, A.O. Cherniavsky // Вестник ЮУрГУ. Серия «Машиностроение». - 2016. - Т. 16, № 3. - C. 15-20. DOI: 10.14529/engin 160302

\section{FOR CITATION}

Baraa M.H. Albaghdadi, Cherniavsky A.O. Possibility of Using Ribs to Protect Pipelines from the Long Crack Propagation. Bulletin of the South Ural State University. Ser. Mechanical Engineering Industry, 2016, vol. 16, no. 3, pp. 15-20. DOI: 10.14529/engin 160302 